\title{
STRUCTURE AND RELATIONSHIPS OF SOME MIDDLE DEVONIAN PLANTS FROM WESTERN NEW YORK ${ }^{1}$
}

\author{
Chester A. Arnold
}

The plant remains described here are some additions to a very interesting flora present in two horizons in the Hamilton group of western New York. The uppermost of the plant-yielding beds is the Tully pyrite, which is so named because it was formerly considered equivalent to the Tully limestone which prominently marks the base of the Upper Devonian in the central part of the state. The limestone itself does not extend into western New York, and recent stratigraphical work indicates that the pyrite bed instead of being a westward extension of the limestone horizon, as was once believed, belongs to the upper part of the Middle Devonian (Hamilton). Although the name "Tully pyrite" is retained as a convenient designation, age identity with the Tully limestone is no longer implied. The other plantbearing horizon is lower and is contained within the Ledyard member of the Ludlowville shale. It is separated from the Tully pyrite by the Moscow shale and the Tichenor limestone which together have a thickness of about fifty feet.

The plants from both horizons are pyritized and show cell structurc, but microscopic examination is possible only with reflected light. In the Tully pyrite the plants occur as wood and stem fragments scattered sparingly among the invertebrate fossils that make up the bulk of the lenticular pyritic masses. Although preservation of the tissues is often good, the preserved parts are small and consist mostly of slivers resulting from the disintegration of larger pieces of wood. All the plant remains described in the present paper were collected in Erie County where they are abundantly distributed throughout the Tully pyrite. Read (1938) also reports their occurrence at the same level in Ontario County. In the Ludlowville shale in Erie County the plants occur in small marcasite nodules embedded in the gray shale, and the most prolific locality is in the bed of Spring Creek just east of the village of Alden. These nodules contain a variety of invertebrate remains as well as plants.

Although Dawson (1862) included brief descriptions of structurally preserved plants from western New York in his inclusive studies of the Devonian plants of eastern North America, no systematic attempts have been made to resume the study of them until recently. In 1935 the present author described two new species from Erie County, and in 1938 Read described additional material from the Tully pyrite at Canandaigua Lake in Ontario County. Altogether six structurally preserved forms are now known from the Hamilton group. These may be listed as follows: Aneurophyton Hallii (Dawson) Arnold comb. nov.; Arachnoxylon Kopfi (Arnold) Read

1 Received for publication October 31, 1939.
(1938); Reimannia aldenense Arnold (1935); Schisopodium Mummii Read (1938); Iridopteris eriensis Arnold gen. et sp. nov.; Xenocladia medullosina Arnold gen. et sp. nov.

Of the genera in the above list, only two, Schizopodium and Aneurophyton, were originally described from elsewhere. Reimannia was first described from the Ludlowville shale at Alden, but has since been recognized in the New Albany shale in Kentucky (Read and Campbell, 1939). The remaining genera, Arachnoxylon, Iridopteris, and Xenocladia, are known only from western New York.

Mr. Irving G. Reimann, of the Buffalo Museum of Science, is mainly responsible for the collections of plant-bearing nodules from the Ludlowville shale at Spring Creek, and Mr. Max J. Kopf, of Lancaster, New York, supplied most of the material from the Tully pyrite.

Iridopteris eriensis gen. et sp. nov. (fig. 1, 5).The name Iridopteris eriensis is proposed for a well preserved axis from the Tully pyrite. The structure measures about $4 \times 5 \mathrm{~mm}$. in cross section, and the shape of the xylem strand is distinctive. The strand is a solid mass of tissue of five "arms" centrally united but so arranged that four are in opposing pairs, with the fifth one occupying a median position to one side (fig. 1). The configuration reminds one of the fleur de lis, which in turn suggests the name Iridopteris. No marked changes have been observed in the xylem at different levels, although the structure has not been followed for a length of more than two centimeters. It is possible that the entire section comes within the limits of a single internode.

Near the extremity of each "arm" are one or two small parenchyma filled spaces (fig. 5), the socalled "peripheral loops." These evidently mark the position of the protoxylem and suggest relationship with certain Paleozoic ferns as the Cladoxylaceae or the Zygopteridaceae. Passing off laterally from the extremities of these "arms" are small traces (fig. 5 at $A$ ) which apparently supply rachial pinnules borne directly upon the main axis between the larger divisions. These have not been followed beyond the point of departure from the main xylem strand. Lying directly opposite the ends of the xylem "arms" are rather large bundles which apparently constitute the traces of the pinnae or whatever type of structure sprang from the axis. Five of these lying opposite the xylem "arms" and in various stages of departure may be observed in a single well preserved cross section. Three traces are indicated in figure 5 at $B, C$, and $D$. (The remaining two are shown in outline but are not lettered.) These larger traces appear to be given off in spiral sequence. Some of them contain an internal parenchymatous area which

[The Journal for January (2T: 1-56) was issued February 2, 1940.] Amfricay Journat. of Botayy, Vor. 27, No. 2, February, 1940. 


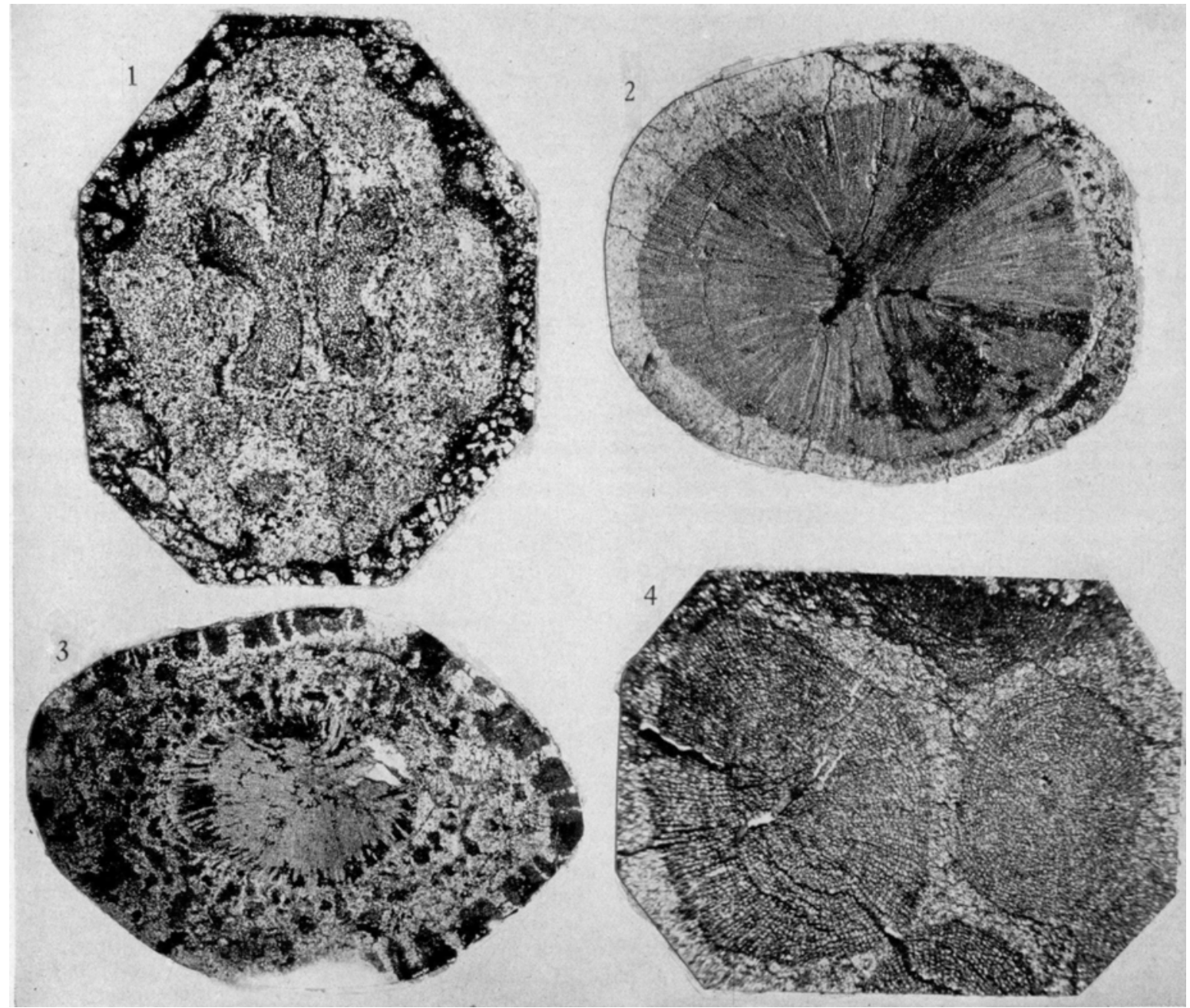

Fig. 1-4.-Fig. 1. Iridopteris eriensis Arnold gen. et sp. nov: 'Transverse section of axis. Tully pyrite. $\times 13 .-F i g .2$. Aneurophyton Hallii (Dawson) Arnold comb. nov. Transverse section showing 3-angled primary xylem surrounded by secondary xylem. Ludlowville shale. $\times 6 \%$. Fig. 3. A. Hallii (Dawson) Arnold comb. nov. Transverse section of stem showing sclerenchyma strands in cortex. $\times 6 \%$. - Fig. 4. Xenocladia medullosina Arnold gen. et sp. nov. Portion of polystelic axis showing two complete steles and portions of three others. Tully pyrite. $\times 20$.

indicates mesarch structure. The small traces do not seem to be arranged in the same spiral sequence as the larger ones.

The clear zone completely surrounding the xylem appears to mark the extent of the phloem (fig. 1), and the large "bays" between the xylem points probably contained considerable parenchyma in addition to phloem. Outside the supposed phloem zone there is a somewhat interrupted layer of cells with dark contents which may be the pericycle. The cortex consists entirely of parenchyma within which the traces are imbedded.

Aside from the odd number of xylem lobes of the strand of Iridopteris the structure is comparable in many respects to the zygopterid and cladoxylaceous phyllophore. In the Zygopteridaceae, however, the pinnae are arranged in two or four rows on the phyllophores, and consequently it would be difficult to in- terpret the five lobed structure of Iridopteris as such an organ. The apparent spiral sequence of the traces in Iridopteris, combined with the symmetry of the axis, indicates an upright structure which was probably the main stem of the plant, and the simplicity of the trace structure suggests small pinnae or simple leaves. The traces may have stopped short of the leaves as in Asteroxylon, but this is mere supposition without supporting evidence.

The two most important anatomical features present in Iridopteris are (1) the parenchymatous areas present near the extremities of the xylem "arms" and (2) and the well developed leaf traces arising apparently in spiral sequence. The first is indicative of affinity with certain Paleozoic fern-like forms belonging to the Cladoxylaceae and the $Z$ ygopteridaceae. Aside from these, the only other group of $\mathrm{Pa}_{\mathrm{a}}$ leozoic plants to which Iridopteris might be assigned 
is the Psilophytales, but both of the features mentioned above render reference to this group undesirable. Another fact to consider is the pronounced bilateral symmetry of the axis which also points to affinities with the ferns. Although bilateral symmetry is exhibited by Asteroxylon elberfeldense, it is not as pronounced as in our form.

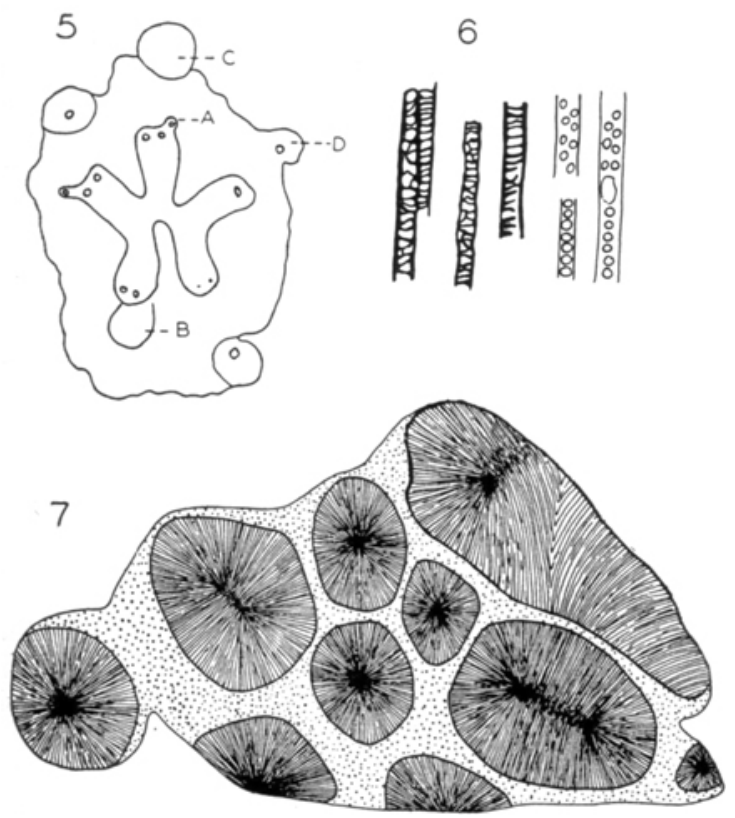

Fig. 5-7.-Fig. 5. Iridopteris eriensis Arnold gon. et sp. nov. Camera lucida outline sketch of transverse section of axis showing shape of the fluted xylem strand and position of peripheral loops and traces. At $A$, small trace; $B, C, D$, three of the five large traces. $\times 6 .-$ Fig. 6 . Xenocladia medullosina Arnold gen. et sp. nov. Longitudinal view of tracheids showing wall sculpturing. $X$ about 35.-Fig. 7. X. medullosina Arnold gen. et sp. nov. Camera lucida outline sketch of transverse section of largest specimen observed showing arrangement of individual steles. $\times 61 / 2$.

Some interesting morphological possibilities are suggested by the xylem strand of Iridopteris. The structure may represent the phyllophore or leaf stalk of a type similar to that possessed by the Cladoxylaceae or the Zygopteridaceae and which in turn was attached to a larger stem or rhizome. Another supposition which seems more plausible is that the axis described represents the main stalk of the plant which in turn is homologous with the zygopterid phyllophore. According to this interpretation, the phyllophore would be the most primitive organ of the aerial part of the plant body. This assumption seems quite in accord with the idea frequently expressed that the prominently lobed xylem strands of some of the Zygopteridaceae, such as Ankyropteris or Asterochlaena, have resulted from a fusion of phyllophore bases. The ultimate validity of this supposition depends upon the acquisition of more information.
Occurring as it does in the Middle Devonian, Iridopteris antedates by a considerable time interval Asteropteris, which occurs in the Portage and which is commonly cited as the oldest known fern.

The problem of fitting a plant of the Iridopteris type into any established scheme of classification is heightened by lack of information concerning foliage and fructifications. Even though the anatomical evidence may be entirely in favor of the establishment of a new group above generic rank, many investigators oppose doing so on such evidence alone. However, there are occasions when such procedure can hardly be avoided, and the dangers confronted are due not so much to the fact that anatomical criteria are employed but rather to the usual inadequacy of any single set of factors in determining relationships. Because of the fragmentary condition of most plant fossils, classification is highly artificial. The only way to classify Iridopteris is to weigh the anatomical evidence carefully and then to decide whether the balance favors reference to any established group. Obviously but unfortunately, such evidence as is lacking (in this case the foliage and fructifications) must be left out of consideration.

In Iridopteris the tips of the xylem "arms" show the parenchymatous areas, or "peripheral loops," near the tips in a similar position to those in Arachnoxylon and Reimannia. Arachnoxylon, however, lacks leaf traces (or at least they have not been observed), and the xylem strand itself is decidedly psilophytic. Read (1938) has referred Arachnoxylon to the Psilophytales, but he also considers it a prototype of the Zygopteridaccae. The present author is in complete agreement with this interpretation of the relative position of Arachnoxylon, although it is believed that it, along with Iridopteris and Reiman$n i a$, is a psilophytic derivative which had definitely attained the primitive fern level. These three genera appear to constitute a series with. Arachnoxylon simplest and nearest the Psilophytales, but Reimannia and Iridopteris more fern-like. If the transitional position of these genera is correctly postulated, it becomes difficult to assign them to either the Psilophytales or the Zygopteridaceae without expanding these groups to unwieldly limits. Within recent years our concept of the Psilophytales has lost all semblance of a natural order by the inclusion in it of so many forms of diverse morphology, and consequently a revision and splitting of it into several orders is almost due. Because of the nebulous boundaries of the Psilophytales as a group, and also the fact that the three genera under consideration reveal definite affinities with the zygopterid ferns, it is believed that they should be classified under the Coenopteridales, preferably as a sub-order for which the name Iridopteridineae is proposed. This suborder may coincide with part of the "Protopteridales" of Zimmermann (1938), an order intended to embrace the so-called "Primofilices" and those fern prototypes (Protopteridium, Aphyllopteris, etc.) showing probable psilophytic connections. 
Coenopteridales, sub-order Iridopteridineae.The sub-order Iridopteridineae is proposed for certain fossil types which show evident psilophytalean affinities and derivation, but which also reveal a definite trend in the direction of the ferns. Obviously, the group occupies an intermediate position. The following definition is built around three structurally preserved forms, and although its exact limits may be subject to modification in the future, the suborder may be tentatively defined as follows:

Stems protostelic with symmetrical, deeply fluted xylem strands; protoxylem mesarch, and one or more parenchymatous areas submerged within the protoxylem region near the tips of the "arms"; leaf traces, if present, simple and spirally arranged; combining psilophytic and fern-like characteristics.

The foliage and fructifications are unknown.

The concept of a group occupying an intermediate position between the ferns and Psilophytales is not new as a similar placement has been proposed for such forms as Protopteridium, Aneurophyton, Pectinophyton, Pseudosporochnus, and Aphlebiopteris (Hirmer, 1938, p. 555). With the exception of $A$ neurophyton, our knowledge of these forms is based almost entirely upon impression material. The fructifications, where known, are small spore sacs borne terminally on small branch ramifications and similar generally to those of the typical members of the psilophyte complex such as Rhynia and Psilophyton, but the general habit is more suggestive of ferns or pteridosperms in most instances. It is not yet possible to correlate evidence of relationship based upon external appearance with that furnished by internal structure of any of the above mentioned forms except Aneurophyton, and consequently it is impossible to state definitely whether any of them should be included within the Iridopteridineae along with the structurally preserved forms. In the present treatment they are not so included, although the possibility that some of them may ultimately find their place there is freely admitted. The uncertainties involved in postulating relationship on the basis of habit and structure is shown by Aneurophyton. Somewhat intermediate between the ferns and Psilophytales in habit, the internal structure of Aneurophyton is suggestive of neither.

It is further proposed that two families be included within the Iridopteridineae as follows: (a) Arachnoxylaceae, based upon the monotypic genus Arachnoxylon (Read, 1938). This contains the simpler and more psilophytic type. (b) Iridopteridaceae including Iridopteris, with one species and Reimannia with two. This family is the more advanced and fern-like.

Were it possible to correlate forms known only from impressions and incrustations with the structurally preserved types, the Protopteridaceae, based upon Protopteridium (Kräusel, 1938, p. 499), might constitute a third family, but as explained above, the Iridopteridineae are limited at present to structurally preserved forms.
Aneurophyton Hallii (Dawson) comb. nov. (Fig. 2,3).-Dadoxylon Hallii Dawson, Quart. Jour. Geol. Soc. London, 18: 306. Pl. XIII, fig. 11. 1862 ; D. Halli Dawson. Geol. Surv. Canada, p. 14. Pl. I, fig. 5 , 6. 1871 ; $D$. cf. Halli Arnold. Bull. Buffalo Soc. Nat. Sci., 17: 2-5. PI. I, fig. 2, 3, 5, 6, 7, 8 . 1935 ; Cordaites Halli Knowlton. Proc. U. S. Nat. Mus. 12: 606. 1889; C. Halli Penhallow. Proc. \& Trans. Roy. Soc. Canada, 6 (4): 74. 1900.

Dadoxylon Hallii was first described by Dawson (1862) from fragments secured from the Tully pyrite in Hemlock Creek, Ontario County, New York. His description, though brief, is sufficient for identification of the secondary wood. A few of the recently. discovered fragments in which the primary portion of the stem is preserved (fig. 2,3) reveal unmistakably the same type of organizations that Kräusel and Weyland (1929, Pl. 3, fig. 8; Pl. 4; Pl. 5, fig. 1, 2) have shown in Aneurophyton. In one specimen (fig. 2) the outline of the three-angled primary $x y-$ lem is strikingly revealed because of partial disintegration of the tracheids and subsequent filling-in of the cavity with mineral matter. The protoxylem was probably situated at the ends of the rather long "arms," but whether the structure is mesarch or exarch cannot be stated at present. Surrounding the three-angled primary xylem mass is a considerable thickness of rather homogeneous secondary wood consisting of tracheids and narrow rays. In the specimen shown in figure 3 the three-angled primary xylem may also be recognized, although less distinctly than in figure 2 because of partial disintegration of the tissues on one side of the axis. In this stem, the tracheids of the primary xylem are preserved, as are also the cortical tissues. The cortex is approximately equal in thickness to the diameter of the xylem. The outer cortex contains a layer of hypodermal sclerenchyma strands separated from each other by intervening parenchyma. Deeper within the cortex are numerous smaller strands showing no special arrangement. Immediately surrounding the secondary wood is a narrow zone of thin-walled cells which presumably represent the phloem and cambium. The structure of the secondary wood has been described previously. In his original account of the species Dawson (1862) mentioned the multiseriate pitting and the numerous narrow rays. The present author (1935) observed that the pits cover the tangential as well as the radial walls of the tracheids and also remarked upon the fact that in this respect the wood resembles that of Aneurophyton.

Wood fragments of $A$. Hallii are the most abundant plant remains in the Hamilton of western New York. In vertical sequence the species appears to range from the Marcellus shale to the Tully pyrite which lies just beneath the Genesee shale. It has not been found in the latter bed. A single fairly large specimen of the secondary wood from the Marcellus shale is the oldest known example of a structurally preserved vascular plant from North America. None of the fragments so far observed exceed $2 \mathrm{~cm}$. in diameter, but several are $10 \mathrm{~cm}$. or more in length. 
Usually only parts of the stems are preserved, and they are often split lengthwise so that the primary structure has been destroyed.

The discovery of a stem in which the trilobed primary xylem strand is surrounded by secondary wood with its tracheids pitted on all walls supplies the first positive evidence of the existence of Aneurophyton in North America. The similarity of habit between Aneurophyton and Eospermatopteris has been commented upon frequently, and both are of similar geological age. The original assumption that Eospermatopteris is a seed plant has been seriously questioned because of the discovery of spores within some of the supposed seeds. On the other hand, the stem of Aneurophyton does not exhibit fern-like structure, and its affinities are probably in the direction of the pteridosperms. Kräusel and Weyland (1929) refer to certain resemblances between the primary xylem strands of Aneurophyton and Stenomyelon, and the latter genus has been shown by Read (1937) to be similar in several important respects to certain members of the Calamopityeae. 'The most striking resemblance is in the three-angled primary xylem. Whether the protoxylem of Aneurophyton is as weakly differentiated as in Stenomyelon has not been determined, but in both it is confined to the points of the primary mass.

The primary xylem of Aneurophyton appears to be a solid mass of tracheids such as exists in the smaller twigs of $S$. tuedianum (described as $S$. tripartitum by Kidston), in which in the larger stems parenchyma is present as bands separating the $x y-$ lem lobes. In $S$. muratum (Read, 1937) the parenchyma is intermixed with the tracheids to produce a "mixed pith." It seems not improbable that Aneurophyton may be a forerunner of the calamopityean complex. During late Devonian and early Carboniferous times the Calamopityeae constituted a diversified group which was probably pteridospermous, although their position is somewhat problematic due to lack of information concerning foliage and fructifications.

Continued investigations of the early land floras may ultimately create the necessity of removing such plants as Aneurophyton and Eospermatopteris from any of the better known plant categories and placing them in a large plexus of synthetic types constituting the primitive stock from which the more specialized forms became segregated along various lines. As is largely true of most of the purely Paleozoic plant groups, such an assemblage would be to a considerable extent artificial and would contain forms of diverse origin as well as the common stock of many later segregates.

Xenocladia medullosina gen. et sp. nov. (Fig. 4 , $6,7)$.- Some fragments of a very interesting polystelic axis were secured from the Tully pyrite. The plant obviously represents a new and unknown type, but because of the fragmentary condition of the material a complete description cannot be given at this time.
It is impossible to form any definite opinion concerning the size of the complete axis, although the largest specimen observed is about $1 \mathrm{~cm}$. in its broadest dimension. Also, it is unknown whether the fragments represent the inner or the outer tissues of the stelar portion. Parts of at least ten steles are present in one specimen (fig. 7). The circular or somewhat elongated steles are $1 \mathrm{~mm}$. or more in diameter and are held together by ground tissue from which all structure has disappeared.

Each stele is in itself a protostele with a complete zone of secondary wood (fig. 4). There is no pith, and the very small primary xylem portion occupies the center. The primary xylem consists only of a few tracheids with no intervening parenchyma. The secondary xylem surrounds the primary xylem to an approximately equal depth on all sides, but its exact inner limits are obscure. Viewed in transverse section, the secondary xylem appears to extend practically to the center. The more oval and elongated strands show evidence of branching into two approximately equal branches. Three such are shown diagrammatically in figure 7 .

Some detail of the sculpturing of the tracheid walls is shown on the split surface (fig. 6). It is sometimes difficult to determine on these fractured surfaces whether a given sculptural type is in the primary or the secondary wood, as the limits of the latter are indefinite, but reticulate and pitted structures are clearly visible. It is assumed that the pitted walls are in the secondary wood and that the reticulate ones are either in the primary portion or in the innermost secondary part. The pit borders are not well preserved, and the shape of the apertures cannot be determined. In most of the pits, the cavities are round, and the pits themselves are rather distantly spaced, with no evidence of crowding (fig. 6 at right). In some of the tracheids the pits are separated vertically from each other by a space as great or greater than the diameter of the pits themselves. A change from the uniseriate to the biseriate arrangement may sometimes be observed within a single tracheid. Whether the pitting in this plant is to be considered as revealing an advanced condition is questionable, although it differs rather markedly from the Dadoxylon type usually occurring in $\mathbf{P a -}$ leozoic stems. Because of the age of the plant, an extremely primitive condition is suspected.

Toward the central part of the stele scalariform and reticulate markings are plainly evident (fig. 6 at left), although it is unknown whether they are confined to the primary wood or extend over into the secondary tissue. The latter alternative seems quite possible in view of the limited extent of the primary wood. At places there are indications of spiral tracheids.

In transverse section the secondary wood appears dense, with small regularly arranged tracheids and narrow rays. No details of ray structure are known.

Because of the fragmentary conditions of the material of Xenocladia medullosina, it is quite impossible to determine with any degree of certainty 
the affinities of this strange axis. The polystelic structure wherein each stele is provided with an independent zone of secondary wood invites comparison with Cladoxylon, Medullosa and Steloxylon. It differs from any known medullosan in its primary structure. A single stele of Medullosa is essentially like that of Heterangium in which there is a large central primary xylem region containing tracheids intermixed with parenchyma. Although the secondary wood surrounding the primary portion may be considerable, the primary part of the medullosan stem is a conspicuous feature of its internal organization. In Xenocladia there is no indication whatsoever of primary structure as extensive as that of $\mathrm{Me}$ dullosa, and in fact, the primary part of the stem is so small that it could not possibly consist of more than a small mass of a very few tracheids.

Xenocladia probably resembles Cladoxylon less closely than it does Medullosa. Scalariform pitting is the rule in Cladoxylon, and its steles are usually elongated in a radial direction. The main reason for mentioning Cladoxylon in connection with Xenocladia is that two species of the latter (C. scoparium and $C$. Darcsoni) occur in the Devonian, whereas no medullosans are known there.

Although Steloxylon is insufficiently known to permit exact comparisons, there are certain points in common between it and Xenocladia. Steloxylon resembles Xenocladia in possessing a polystelic axis in which some of the individual steles are circular in transverse section and others are elongated. Another feature of probable greater significance is the fact that the Steloxylon stele consists mainly of secondary wood. The structure of the central portion of the Steloxylon stele is not well known, but as nearly as has been determined it possesses a parenchymatous center instead of a solid tracheid mass. The main resemblance, however, is that in both forms the amount of primary development is slight as compared with other polystelic forms as Medullosa or Cladoxylon. Xenocladia bears a further resemblance to Steloxylon in having bordered pits on at least some of the tracheid walls.

The protostelic structure of the individual strands of Xenocladia is suggestive of a root, and the possibility must be entertained that this stelar mass belongs to a plant in which the root zone constitutes a well organized tissue outside the stem, as in $\mathbf{P s a}-$ ronius. Psaronius roots, however, lack secondary growth, and it may be recalled that Paul Bertrand suggested that possibly Steloxylon is the root of Cladoxylon.

The combination of characters present in Xenocladia seems to be unique and without direct analogy among Paleozoic plants. That the structure is simple and in some respects primitive can scarcely be questioned, and it is possible that it represents some type of undifferentiated vascular axis which is nearly on a level with the Psilophytales. The central portion of each stele consisting as it does of a solid tracheary mass strongly recalls that of the simple vascular plants of the Rhynia type. Furthermore, branching similar to that in Rhynia may be revealed in the apparent forking of some of the steles (fig. 4, 5). Against the psilophytalean interpretation of Xenocladia is the polystelic structure and the well developed secondary wood. However, secondary growth, like heterospory, seems capable of independent origin in almost any vascular plant group, and it would be presumptuous to assume dogmatically that it did not occur in at least some members of the psilophyte complex. Such development is actually foreshadowed in Schizopodium. Without the aid of more complete material further considerations of the affinities of Xenocladia would be purely speculative, although from the bulk of evidence at hand it seems permissible to place it tentatively in the somewhat indeterminate pteridospermous family, the Steloxylaceae. Xenocladia may ultimately prove to be a representative of some intermediate stage between the Psilophytales and certain of the polystelic pteridosperms.

\section{SUMMARY}

Structurally preserved plant remains from the Tully pyrite and the Ludlowville shale of upper Middle Devonian (Hamilton) age are described. Iridopteris eriensis is made the type of a new suborder, the Iridopteridineae, which is intermediate between the Psilophytales and the ferns. Within this sub-order are Reimannia and Arachnoxylon. Two families, the Arachnoxylaceae and the Iridopteridaceae, are distinguished. The xylem strand in the members of the Iridopteridineae is a fluted, mesarch structure with prominent "peripheral loops" near the extremities of the "arms." Leaf traces are present in Iridopteris and Reimannia, and these genera are construed as more fern-like than Arachnoxylon, from which leaf traces are absent. Stems with secondary wood which occur rather abundantly in the Hamilton of western New York and which are described by Dawson as Dadoxylon Hallii are referred to Aneurophyton on the basis of primary structure. Xenocladia medullosina is a polystelic axis of obscure affinities. It contains several small protosteles held together by a common ground mass. Each stele is surrounded by a complete zone of secondary xylem, and the primary xylem is small in amount. The genus is tentatively referred to the Steloxylaceae. This is the oldest structurally preserved vascular flora to be described from North America.

\section{University of Michigay,} Axy Arror, Michigax

\section{LITERATURE CITED}

Arvoln, C. A. 1935. Some new forms and new occurrences of fossil plants from the Middle and Upper Devonian of New York State. Bull. Buffalo Soc. Nat. Sci. 17 : 1-12.

Dawsox, J. W. 1862. On the flora of the Devonian period in northeastern America. Quart. Jour. Geol. Soc. London 18: $296-330$.

Hinmer, M. 1938. Pteridophyta Incertae Sedis. In Verdoorn, Fr. Manual of Pteridology. The Hague. 
KräuseL, R. 1938. Psilophytinae. In Verdoorn, Fr. Manual of Pteridology. The Hague.

—_, ANd H. Weytaxd. 1929. Beitrïge zur Kenntnis der Devonflora. III. Abh. Senken. Naturf. Gesell. 41: $315-360$.

REAd, C. B. 1937. 'The flora of the New Albany shale. Part 2. The Calamopityeae and their relationships. U. S. Geol. Surv., Prof. Pap. 186-E.
1938. Some Psilophytales from the Hamilton group in western. New York. Bull. Torrey Bot. Club $65: 599-606$.

- and G. Camprele. 1939. Preliminary account of the New Albany shale flora. Amer. Midl. Nat. 21: $435-448$.

Zummermaxs, W. 1938. Phylogenie. In Verdoorn, Fr. Manual of Pteridology. The Hague.

\title{
STUDIES IN THE GENUS SCIRPUS L. I. DELIMINATION OF 'THE SUBGENERA EUSCIRPUS AND APHYLLOIDES ${ }^{1}$
}

\author{
Alan A. Beetle
}

Scinpus, a genus of the Cyperaceae, was erected by Linnaeus (1753) to include 24 species. Subsequently there have been proposed in the genus approximately 800 names and combinations of specific rank. A conservative estimate as to how many of the names actually represent valid entities within the defined generic limits of Scirpus is impossible at this time. The number 200 is frequently given.

$\mathrm{Pax}$ (1887) divided the genus into the subgenera Isolepis (Link, 1821) and Euscirpus (Grisebach, 184.4) upon the absence or presence of perianth bristles. As early as 1901 Fernald pointed out that this character in itself was insufficient even for the recognition of species. Scirpus smithii Gray either lacks bristles or has mere rudiments, while in its varieties setosus Fernald and levisetus Fassett (1921) they are always present. Scirpus debilis Pursh has bristles, while in its variety reilliamsii Fernald they are lacking.

Again, within a widely separate series it is found that Scirpus robustus Pursh has bristles variably from one to six or absent. The number of bristles occurring in the related species, Scirpus paludosus Nelson, has been reported as from one to three, two to six, usually two, and none.

The situation in Scirpus is apparently similar to that in the genus Eleocharis (Svenson, 1929-1939) of the same cyperaceous tribe, Scirpeae. Many examples of the variability of bristles in this genus may be cited. E. acicularis (L.) Roem. \& Schult. has three to four bristles equaling the achene or bristles absent; in E. palustris (L.) Roem. \& Schult. are found variously four bristles shorter than or equaling the achene or absent. E. bella (Piper) Svenson has bristles absent; $E$. obtusa (Willd.) Schult. has six or seven bristles consistently present. Svenson has only rarely used perianth characters in his keys -e.g., in separating E. schzeeinfurthiana Boeckler (bristles present) from E. nigrescens (Nees) Steudel (bristles lacking). It would be surprising if in a genus as close to Eleocharis as Scirpus there were sufficient stability in the bristles to be of significance. Study has shown the bristles to be highly variable as to number and character and consequently of only limited taxonomic value.

From an examination of a large body of material the species of the genus Scirpus appear to fall into

${ }^{1}$ Received for publication November 6, 1939. the following subgenera based upon the nature of the involucre and the relative development of the cauline leaves.

EuscrRpus Griseb. (emend.) Involucre of foliaceous bracts; cauline leaves usually well developed.

APIY YLLOIDES Involucre of non-foliaceous bracts; cauline leaves usually greatly reduced.

These subdivisions of approximately equal size conform to the natural affinities of the contained groups. Scirpus sylvaticus L., the type species of the genus, must be taken as typical of the subgenus Euscirpus. Since none of the numerous, already established subdivisions of Scirpus has used the character of the involucre as a primary consideration, the entirely new subgeneric name, Aphylloides, is given for the group of which $S$. lacustris L. is typical.

Palla (1889) studied cross-sections of the stems of a variety of species in Scirpus and related genera, suggesting eight genera largely based on the distribution of vascular tissue. More recently Monoyer (1934) in a comprehensive treatment of the anatomy of Scirpus concludes that Scirpus sylvaticus typifies the basic stock and that the derived types show two tendencies: (1) a reduction in the number of leaves and (2) a reduction in the vascular system. Monoyer is able on this basis to construct a family tree for the genus, placing Scirpus sylvaticus and Scirpus maritimus and their allies (his section Phylloscirpus) in close association as representative of the primitive condition. From this group there have developed three general tendencies, one culminating in the section Baeothryon (S. cespitosus and its allies), one in the section Eleogiton (S. fluitans and its allies) and a third leading to a rather polymorphic group including S. lacustris, S. americanus, S. mucronatus, $S$. setaceus, and their allies (his section Schoenoplectus). This treatment is based solely on European material and is correlated with the ecological but not with the geographical distribution of the species concerned. Although a considerable amplification and modification of the abbreviated phylogenetic tree of Scirpus as given by Monoyer will be necessary, the general treatment is in accord with the divisions proposed in this paper. Of the four sections listed by Monoyer Phylloscirpus here equals Euscirpus, while the sections Schoenoplectus, Baeothryon, and Eleogiton are included under Aphylloides. 